\title{
EFFECTS OF ENRICHED ENVIRONMENT ON MAXIMAL LACTATE STEADY STATE OF WISTAR RATS
}

\author{
EFEITOS DO AMBIENTE ENRIQUECIDO NA MÁXIMA FASE ESTÁVEL DO \\ LACTATO DE RATOS WISTAR
}

\section{Lucas Figueiredo JORDÃO ${ }^{1}$; Ricardo Augusto BARBIERI ${ }^{2}$; Welton Ferreira de ASSIS $^{3}$; Wonder Passoni HIGINO ${ }^{4}$; Julio Wilson dos SANTOS ${ }^{5}$; José Alexandre Curiacos de ALMEIDA LEME ${ }^{6}$}

1. Discente do Centro Universitário Católico “Auxilium" Unisalesiano; 2. Doutorando pelo Programa de Pós Graduação em Ciências da Motricidade-UNESP-Rio Claro; 3. Mestrando pelo Programa de Pós Graduação em Ciências da Motricidade-UNESP-Rio Claro; 4Docente no Instituto Federal de Educação, Ciência e Tecnologia do Sul de Minas Gerais - Campus Muzambinho, Minas Gerais,Brasil; 5. Docente pelo Programa de Pós Graduação em Ciências da Motricidade-UNESP-Rio Claro e Unesp Bauru; 6. Docente do Centro Universitário Católico “Auxilium” Unisalesiano, do Programa de Pós Graduação em Ciências da Motricidade-UNESP-Rio Claro e da Unesp Bauru-zecuriacos@terra.com.br

\begin{abstract}
The enriched environment (EE) is a combination of stimulations inserted in the cage, such as tunnels, exercise wheel and color objects, increased cage size and the number of rats. Although the EE can be promoter of physical activity (PA), the literature lacks studies showing the effects of this accumulation of PA in the rats. In this way, the present study aims to investigate the effects of EE on maximal lactate steady state in rats. To this, adult Wistar rats were randomly distributed into control group (CG), kept in conventional cages, and EE group (EEG), kept in enriched cages. Before and after the experimental period (six weeks) the animals were submitted for the maximal lactate steady state (MLSS) test. In the last week, length and body mass was measured. At the end of the experimental period, after euthanasia, blood sample was collected for the analyses of glucose and heart was weighted. To statistical analyses, after the test of normality, the parametric results were analyzed by Student's $t$ test and nonparametric through Mann-Whintey test. There were no differences in serum glucose, body length, body and heart mass. The groups presented similar MLSS at beginning of experiment, however, MLSS load was higher in EE than CG at end of experiment. In conclusion, PA performed in the enriched cage increased the aerobic capacity in comparing to the conventional cage, even in the absence of significant changes in length and body weight and blood glucose.
\end{abstract}

KEYWORDS: Enriched environment. Physical activity. Lactate.

\section{INTRODUCTION}

The environment can trigger many adaptation and survival responses in living beings. In their environment, the living being is stimulated to develop skills and abilities that will allow its survival and maintenance of the specie.

The enriched environment can be defined as "a combination of complex inanimate and social stimulations" which provides to the living being that dwelled therein better conditions for its development (ROSENZWEIG, 1978). Some objects are inserted into the animal's environment, such as tunnels, exercise wheel and color objects with the objective of stimulating the animals to exercise their sensory, motor, cognitive, social and behavioral processes (SZTAINBERG; CHEN, 2010). In laboratories, animal experimentation can be improved using this enriched environment, bringing benefits to the quality of life of the animals and making the behavior closer to the actual response of the organism (BAUMAN, 2005).

\begin{abstract}
Several
studies

have demonstrated important effects of enriched environment to the animal, such as cognitive and neurogenic improvements (SOUNBACKJUNGERMAN et al., 2005), reduction of apoptosis and tissue destruction (WILLIAMSON et al., 2012) and increase of brain derived neurotrophic factor (BDNF) (SEGOVIA et al., 2008a; YOUNG et al., 2004). However, studies have demonstrated that among the factors that contribute to the improvements found in enriched environment, physical activity seems to be primordial factor (KOBILO et al., 2011; MUSTROPH et al., 2012). In a recent study, Xie and his collaborators (2013) demonstrated that the maintenance of enriched environment promotes an increase in speed, duration, distance and frequency of movement, being promoter of physical activity either by increasing the space, number of animals or inanimate elements therein maintained. However, to our knowledge, any study has investigated the magnitude of these effects on aerobic conditioning of animals.
\end{abstract}


In rodents, exercise experimental model traditionally uses forced exercise as swimming and running in treadmill or the voluntary physical activity (VPA) and the spontaneous PA (SPA) also are studied as another forms of physical activity (GARLAND et al., 2011). For study the voluntary physical activity is common insert wheel of activity in individual cages. However, the VPA and SPA can be more widely studied when the animal can develop their motor and behavioral processes, as occurs in enriched cages. Nevertheless, little is known about the accumulation of physical activity in enriched environment and its influence on the aerobic capacity in rats.

To verify the effects of increased aerobic capacity, the determination of maximal lactate steady state (MLSS) has been considered the gold standard in human (MANCHADO et al., 2005). MLSS represent the balance between production and removal of lactate and is determined in several continuous exercise bouts to verify what the higher intensity in which lactate vary not more than 1 mmol/L (BILLAT et al., 2003). MLSS was adapted for swimming exercise in rats (GOBATTO et al., 2001) and can be used verify difference between aerobic capacity in exercise experimental model with rats. The aim of this study was to verify the effects of maintenance of wistar rats in enriched environment on MLSS, blood glucose and body parameters.

\section{MATERIAL AND METHODS}

\section{Animals}

This study was conducted at Centro Universitário Católico Unisalesiano Auxilium, using male Wistar rats (Rattus norvecigus albinus wistar), 70 days old, from the university bioterium and kept in collective cages in a light/dark cycle of $12 / 12$ hours, with the temperature controlled at $25^{\circ} \mathrm{C}$ and free access to water and food. The tests were performed in the morning, and the cleaning of cages performed in the afternoon.

The animals were treated in accordance with the Guide for Care and Use of Laboratory Animals and the project was analyzed and approved by the committee for ethics in animal experimentation (Institutional commission for ethics in animal experimentation, protocol 005). The animals were randomly distributed into the following groups: control group (CG): animals kept in conventional cages during the six weeks of the experimental period; enriched environment group (EEG): animals kept in enriched cages during the six weeks of the experimental period.

\section{Enriched Environment}

The enriched cage was assembled based on protocol described by Sztainberg and Chen (2010) and adapted for the species and age of the animals. The enrichment consisted in making the cage an environment abundant in sensory stimulation, produced by inanimate objects such as a wheel of activity, pipes and toys, giving to animals opportunities for sensory stimulation. In addition, the enriched cage $(100 \times 60 \times 40)$ was bigger (2-3 fold) than the conventional cage $(41 \times 34 \times 16)$. Six animals were housed in enriched cage and three in the control cage. The largest number of rats in EE allows greater social contact between the animals. The animals were maintained throughout the experimental period in the respective cage (EE or $\mathrm{CG})$.

Determination of the maximal lactate steady state (MLSS)

The animals were subjected to the aerobic capacity test for the identification of the maximal lactate steady state (MLSS), according to Gobatto and collaborators (2001). The MLSS was determined before and after six weeks of the experimental period. For the determination of MSSL the animals carried out several tests of swimming supporting constant overloads in relation to their body mass (bm), in different days. Each test consisted of 30 minutes of uninterrupted swimming. The objective of test is to determine the higher load in which the blood lactate present stabilization, i.e., difference lesser than or equal to $1.0 \mathrm{mmol} / \mathrm{L}$ between $10^{\text {th }}$ and $25^{\text {th }}$ minutes of exercise. The first test was performed with the load of $5 \% \mathrm{bm}$ and variation of $0.5 \%$ to above or below, until to found the maximum load in which still occurs stabilization of blood lactate concentration during the exercise session.

Blood samples was collected through a puncture at the end of the tip of the tail of animal, every 5 minutes of exercise for the analyses of lactate concentrations. The blood samples $(25 \mu \mathrm{l})$ were transferred into Eppendorf (1.5 ml capacity) tubes containing $50 \mu \mathrm{L}$ of sodium fluoride $(1 \%)$. The blood lactate concentrations were determined in a lactate analyzer (Lactimeter: YSI Model 1500 Sport, Yellow Springs, OH, USA).

\section{Evaluations after euthanasia}

At the end of the experimental period (7 weeks), after euthanasia and without fasting, the blood was collected and the serum was separated by centrifugation and glucose measured by commercial kits (Wiener $\mathrm{Lab}^{\circledR}$ ). The heart was sectioned and its mass was recorded using analytical 
scale to investigate possible cardiac alterations promoted by EE. The animals had their length nasoanal using a rule and body mass using a scale. The Lee Index was calculated dividing the cube root of body weight in grams by naso -anal length in centimeter and multiplying ten (BERNARDIS, 1968)

\section{Statistical Analysis}

After the test of normality, the parametric results were statistically analyzed using Student's t- test and the nonparametric through the test of MannWhintey being used for both the software SPSS®.

\section{RESULTS}

There was no significant difference between animal kept in conventional cages or enriched cage. Similarly, there were not significant differences in body length and the mass of the heart between the animals of groups studied (Table 1).

Table 1. Body length, Lee Index, heart and body mass of the animals in the control and enriched environment groups after six weeks of experimental period.

\begin{tabular}{|c|c|c|c|c|}
\hline Parameters & $\begin{array}{l}\text { Body Mass } \\
\text { (g) }\end{array}$ & $\begin{array}{l}\text { Body Length } \\
\text { (cm) }\end{array}$ & Lee index & $\begin{array}{l}\text { Heart mass } \\
\text { (g) }\end{array}$ \\
\hline Control & $399.2 \pm 35.6$ & $26.7 \pm 0.8$ & 0.27 & $1.36 \pm 0.06$ \\
\hline Enriched environment & $389 \pm 39.5$ & $27.1 \pm 1.1$ & 0.27 & $1.32 \pm 0.07$ \\
\hline
\end{tabular}

Values were expressed as mean \pm standard deviation. Student's t-test; $n=6$ rats per group.

The blood glucose did not present significant difference between the groups (Figure 1). The Figure 2 shows the MLSS loads before and after the experimental period. At beginning of the experimental period (pre) the MLSS load was similar between groups, however, at end of experiment (post) animals of EEG presented higher MLSS load in comparing to the CG.

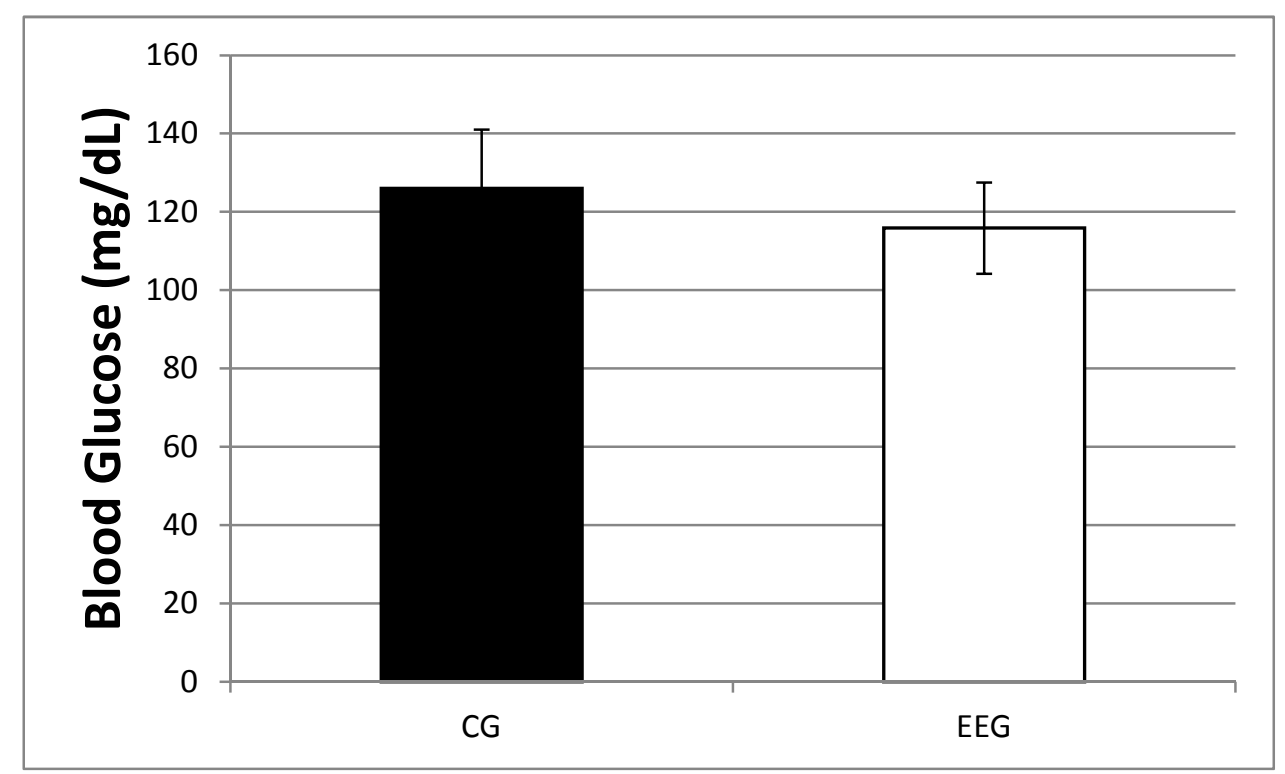

Figure 1. Blood glucose $(\mathrm{mg} / \mathrm{dL})$ of animals belonging to the control group (CG) and enriched environment group (EEG) at the end of the experimental period. Values expressed as mean \pm standard deviation. Student's t-test; $\mathrm{n}=6$ rats/group. 


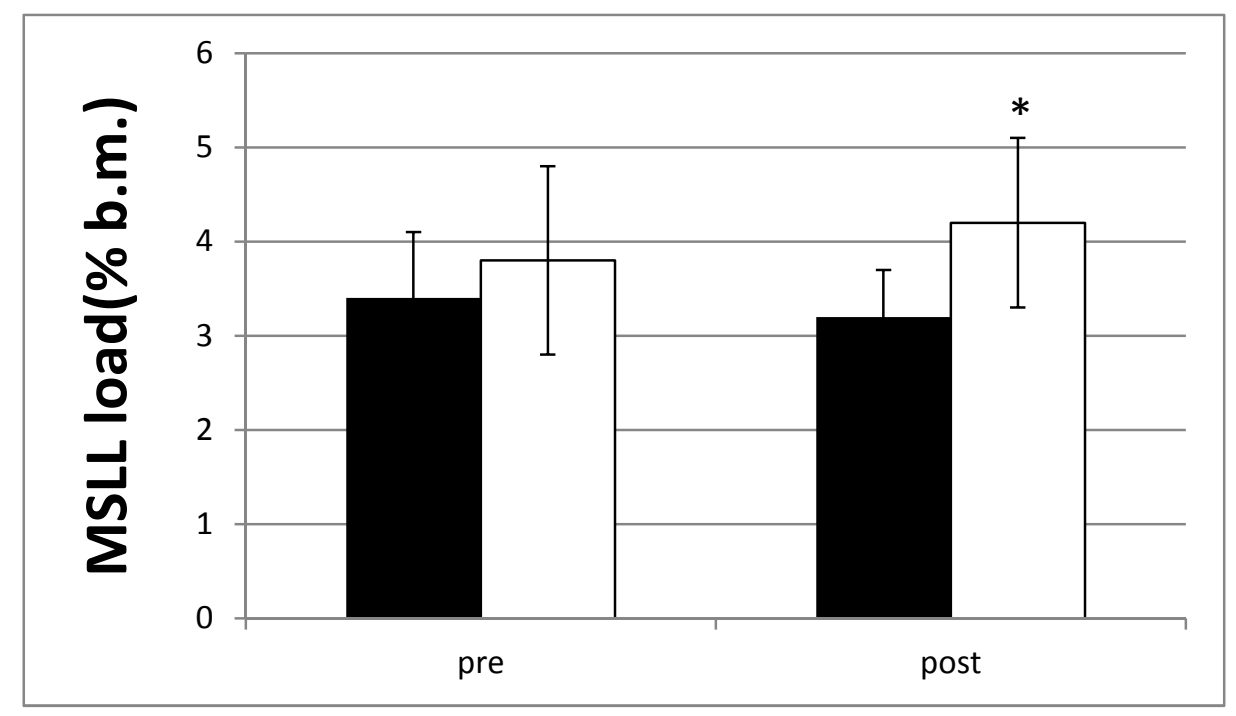

Figure 2. Load that the animals reached the maximal lactate steady state (MLSS) belonging to the control group (CG) and enriched environment group (EEG) pre and post the experimental period. Values expressed as mean \pm standard deviation. Student's t-test; $n=6$ rats/group. Black: CG, White: EEG. *Significant difference between GC and EEG at end of experiment $(\mathrm{p}<0.05)$

\section{DISCUSSION}

The aim of this study was to verify the housing effects of wistar rats in enriched environment on MLSS, blood glucose and body parameters. The body parameters and blood glucose showed no significant difference between groups CG and EEG. However, at end of experimental period, MLSS load was higher in EEG in comparing to the $\mathrm{CG}$.

The accumulation of VPA and SPA is usually measured with the animals kept in individual cages. Considering the accumulated physical activity in enriched cage, animals may change their energy balance. However, few studies have investigated changes in body mass in animals housed in enriched cages and the results are imprecise. In the present study, despite the increased cage size and presence of the exercise wheel that, supposedly, increase the accumulation of physical activity in enriched cage, there was no significant difference at end of experiment in body mass. Beale and collaborators (2011) registered rigorously the food intake and body mass of animals whose cages received elements of enriched cage and found no significant differences between the groups. However, in this particular study, cages had equal size and has no wheel of exercise. Using the wheel of exercise to promote VPA, Suzuki and colleagues (1992) have found a reduction in total body mass around 9\%, as well as Worthand et al (2009) found a significant reduction in body weight of animals kept for long period in an enriched environment.
The animals housed in standardized cage (Malau Cage) since the fourth week of life during six weeks led to an increase in body weight (FARES et al., 2013). Tsai et al. (2002) also found no changes promoted by enriched environment in body and heart mass. Heart mass also was not different between groups. The analysis only of body mass isolated is a limitation of present study. Food intake and body composition may offer more information and should be verified in future studies.

The blood glucose of EEG in comparing to the CG was not significant. The benefits of physical activity to improve the action of insulin, increase of glucose transporters (GLUT) and reduction of blood glucose levels are classic (RICHTER; HARGREAVES, 2013). For animals kept in cages with wheel of exercise, there was an increased GLUT4 expression in soleus and plantar muscles (GULVE et al., 1993) and improved insulin action and glucose uptake (LAPIER et al., 2001). In diet- induced insulin-resistant animals, there was an increasing in insulin mediated by hepatic insulin sensitizing substance (CHOWDHURY; LEGARE; LAUTT, 2013a). Is necessary to emphasize that, in both groups, the animals were normoglycemic. The effects of the enriched cage housed hyperglycemic animals can be investigated in future studies.

The study of the effects of physical activity on animals can be executed in several ways. Basically, the authors propose an initial classification in forced exercise, voluntary physical activity and spontaneous physical activity 
(GARLAND et al, 2011). For the study of the forced physical exercise, are widely used treadmill and swimming pool. The study of voluntary physical activity is usually carried out in animals kept in small individual cages containing the wheel of exercise and spontaneous physical activity is measured using the calorimetry (GARLAND et al., 2011).

In the MLSS test performed at beginning of experiment, when the animals of both groups were kept in cages conventional, there was no significant difference. However, after six weeks of experimental period, the MLSS of animals kept in cages enriched was significantly higher than animals kept in conventional cage. This data demonstrate that the animals kept in enriched cages had better aerobic conditioning that animals kept in conventional cages, supposedly, due to more accumulation of physical activity in enriched environment.

To our knowledge, there is no study in the literature, which evaluates effect of enriched environment on aerobic capacity. However, some studies have demonstrated that physical activity is an important factor for the changes of others parameters in enriched environment. Kobilo and colleagues (2011) demonstrated that physical activity is a critical factor for the increase in brainderived neurotrophic factor (BDNF) and hippocampal neurogenesis in animals kept in enriched environment. Mustroph and collaborators (2013) also demonstrated that voluntary physical activity promoted an increase in neurogenesis and an improvement in performance in mazes. Keeping animals in enriched cages promotes an increase in accumulation of physical activity, but there is lack of researches to measure this increase (KOBILO et al., 2011). In a recent study, Xie and colleagues (2013) demonstrated through filming technique that the enriched environment increased the speed, duration, distance and frequency of dislocations of animals, proving higher accumulation of physical activity. These preview findings contribute to explain why the EEG animals of present study showed higher MLSS loads comparing to the CG, despite of the type of exercise used as a means of assessment (swimming) is different in which the animals carried out in enriched environment.

Several methods have been used to measure the accumulation of physical activity in animals, as accelerometers, sensors and video footage (SHIH, YOUNG, 2007; GARLAND et al., 2011). However, these methods allow access only to locomotion or activity on the wheel, disregarding other forms of spontaneous physical activity such as smelling, rising or fighting. The improvement in aerobic conditioning can be a signal of alterations in the accumulation of physical activity (ARQUER et al., 2006) as well as blood lactate can used to discriminate level of conditioning (DOS-SANTOS; MELLO, 2010) and aerobic intensity (DosSANTOS; MELLO, 2011) in swimming exercise with rats. In this way, in the present study the MLSS was performed before and after the experimental period to investigate the effects of enriched environment on aerobic conditioning of animals promoted by maintenance in enriched cages.

In conclusion, the enriched environment improved the aerobic capacity of rats, verified by MLSS load, whereas the blood glucose and body parameters showed no difference in comparing to the control sedentary animals.

\section{ACKNOWLEDGEMENTS}

The authors thank Research Pro-rector of Unisalesiano for financial support.

RESUMO: O ambiente enriquecido (EE) é uma combinação de estímulos inseridos na gaiola, tais como túneis, roda de exercício e objetos coloridos, além de aumento do tamanho da gaiola e do número de ratos. Embora o EE possa ser promotor de atividade física (PA), a literatura carece de estudos mostrando os efeitos dessa acumulação de PA em ratos mantidos no EE. Desta forma, o presente estudo tem como objetivo investigar os efeitos do EE sobre a máxima fase estável do lactato. Para isso, ratos Wistar adultos foram distribuídos aleatoriamente em grupo controle (CG), mantidos em gaiolas convencionais e grupo AE (EEG), mantidos em gaiolas enriquecidas. Antes e após o período experimental (seis semanas), os animais foram submetidos ao teste de máxima fase estável do lactato (MLSS). Na última semana, comprimento e massa corporal foram registradas. No final do período experimental, após a eutanásia, amostra de sangue foi coletada para análise de glicose e a massa do coração foi registrada. Para as análises estatísticas, após o teste de normalidade, os resultados paramétricos foram analisados pelo teste $\mathrm{t}$ de Student e não paramétrico através do teste de Mann-Whintey. Não houve diferença nos níveis de glicose no soro, comprimento corporal e massa cardíaca. Os grupos apresentaram MLSS semelhante no início do experimento, no entanto, no final do experimento, a carga da MLSS foi maior no EEG comparado ao GC. Em conclusão, PA realizada na gaiola enriquecido aumentou a capacidade aeróbia em comparação com o grupo mantido em gaiolas convencionais, mesmo na ausência de mudanças significativas na massa e comprimento corporal e da glicemia. 
PALAVRAS-CHAVE: Ambiente enriquecido. Atividade Física. Lactato.

\section{REFERENCES}

ARQUER, A. et al. Amount and intensity of physical activity, fitness, and serum lipids in pre-menopausal women. International journal of sports medicine, New York, v. 27, n. 11, p. 911-918, 2006.

BEALE, K. et al. Accurate measurement of body weight and food intake in environmentally enriched male Wistar rats. Obesity, Silver Spring, v. 19, n. 8, p. 1715-1721, 2011. http://dx.doi.org/10.1038/oby.2010.331

BILLAT, V. L. et al. The concept of maximal lactate steady state. Sports Medicine, v. 33, n. 6, p. 407-426, 2003. http://dx.doi.org/10.2165/00007256-200333060-00003

BERNARDIS, L. L.; PATTERSON, B. D. Correlation between "Lee index" and carcass fat content in weanling and adult female rats with hypothalamic lesions. J. Endocrinol, Bristol, 1968; 40:527-528.

http://dx.doi.org/10.1677/joe.0.0400527

BRUEL-JUNGERMAN, E.; LAROCHE, S.; RAMPON, C. New neurons in the dentate gyrus are involved in the expression of enhanced long-term memory following environmental enrichment. European Journal of Neuroscience, Oxford, v. 21, n. 2, p. 513-521, 2005. http://dx.doi.org/10.1111/j.1460-9568.2005.03875.x

CHOWDHURY, K K.; LEGARE, D J.; LAUTT, W. Interaction of antioxidants and exercise on insulin sensitivity in healthy and prediabetic rats. Canadian journal of physiology and pharmacology,Otawa, v. 91, n. 7, p. 570-577, 2013.

DOS-SANTOS, J W.; DE MELLO, M A R. Responses of Blood Lactate Concentration in Aerobic and Anaerobic Training Protocols at Different Swimming Exercise Intensities in Rats. Journal of Exercise Physiologyonline, Duluth, v. 14, n. 3, 2011.

FARES, R P. et al. Standardized environmental enrichment supports enhanced brain plasticity in healthy rats and prevents cognitive impairment in epileptic rats. PloS one,San Francisco, v. 8, n. 1, p. e53888, 2013.

GARLAND, T et al. The biological control of voluntary exercise, spontaneous physical activity and daily energy expenditure in relation to obesity: human and rodent perspectives. The Journal of experimental biology, London, v. 214, n. 2, p. 206-229, 2011.

GOBATTO, C A et al. Maximal lactate steady state in rats submitted to swimming exercise. Comparative Biochemistry and Physiology Part A: Molecular \& Integrative Physiology, New York, v. 130, n. 1, p. 2127, 2001. http://dx.doi.org/10.1016/S1095-6433(01)00362-2

GULVE, E A. et al. Effects of wheel running on glucose transporter (GLUT4) concentration in skeletal muscle of young adult and old rats. Mechanisms of ageing and development, Lausanne, v. 67, n. 1, p. 187-200, 1993.

KOBILO, T et al. Running is the neurogenic and neurotrophic stimulus in environmental enrichment. Learning \& Memory, New York, v. 18, n. 9, p. 605-609, 2011. http://dx.doi.org/10.1101/1m.2283011

LAPIER, T L. K et al. Voluntary running improves glucose tolerance and insulin resistance in female spontaneously hypertensive rats. American journal of hypertension, Oxford, v. 14, n. 7, p. 708-715, 2001.

MANCHADO, F. B. et al. Maximal lactate steady state in running rats. J Exerc Physiol, Duluth, v. 8, p. 29-35, 2005. 
MUSTROPH, M L. et al. Aerobic exercise is the critical variable in an enriched environment that increases hippocampal neurogenesis and water maze learning in male C57BL/6J mice. Neuroscience, oxford, v. 219, p. 62-71, 2012.

PEÑA, Y et al. Enduring effects of environmental enrichment from weaning to adulthood on pituitary-adrenal function, pre-pulse inhibition and learning in male and female rats. Psychoneuroendocrinology, Oxford, v. 34, n. 9, p. 1390-1404, 2009. http://dx.doi.org/10.1016/j.psyneuen.2009.04.019

RICHTER, E A.; HARGREAVES, M. Exercise, GLUT4, and skeletal muscle glucose uptake. Physiological reviews, Bethesda, v. 93, n. 3, p. 993-1017, 2013.

ROSENZWEIG, M R. et al. Social grouping cannot account for cerebral effects of enriched environments. Brain research, Amsterdam, v. 153, n. 3, p. 563-576, 1978.

SEGOVIA, G et al. Effects of an enriched environment on the release of dopamine in the prefrontal cortex produced by stress and on working memory during aging in the awake rat. Behavioural brain research, Amsterdam, v. 187, n. 2, p. 304-311, 2008.

SHIH, Y H; YOUNG, M. Integrated digital image and accelerometer measurements of rat locomotor and vibratory behaviour. Journal of neuroscience methods, Amsterdam, v. 166, n. 1, p. 81-88, 2007.

SUZUKI, K.; MACHIDA, K.; KARIYA, M. [Conditions for low-intensity voluntary wheel running in rats and its chronic effects on health indexes].Nihon eiseigaku zasshi. Japanese journal of hygiene, Tokyo, v. 47, n. 5, p. 939-951, 1992.

SZTAINBERG, Y; CHEN, A. An environmental enrichment model for mice. Nature protocols, London, v. 5, n. 9, p. 1535-1539, 2010.

TSAI, P.-P. et al. Impact of environmental enrichment in mice. 1: Effect of housing conditions on body weight, organ weights and haematology in different strains. Laboratory animals, London, v. 36, n. 4, p. 411-419, 2002.

XIE, $\mathrm{H}$ et al. Enrichment-induced exercise to quantify the effect of different housing conditions: A tool to standardize enriched environment protocols. Behavioural brain research, Amsterdam, v. 249, p. 81-89, 2013.

YOUNG, N A.; WINTINK, A J.; KALYNCHUK, L E. Environmental enrichment facilitates amygdala kindling but reduces kindling-induced fear in male rats. Behavioral neuroscience, Washington, v. 118, n. 5, p. 1128, 2004.

ZAGATTO, A M et al. Assessment of aerobic capacity through blood and ventilatory responses in four different ergometers. Revista Brasileira de Cineantropometria \& Desempenho Humano, Florianópolis, v. 15 , n. 3, p. 350-360, 2013. 